\title{
In vitro Efficacy of Plant Extracts against Bipolaris setariae causing Brown Top Millet Leaf Blight
}

\author{
Gutha Venkata Ramesh ${ }^{1 *}$, K. B. Palanna ${ }^{2}$, Arunkumar ${ }^{1}$, \\ Boda Praveen ${ }^{1}$ and A. Nagaraja ${ }^{1}$
}

${ }^{1}$ Department of Plant Pathology, University of Agricultural Sciences, Bangalore, India

${ }^{2}$ Project Coordinating Unit, ICAR-AICRP on Small millets, ZARS, GKVK, Bengaluru, India

*Corresponding author

\section{A B S T R A C T}

Keywords

Browntop millet, $B$. setariae, In vitro, Botanicals, Agave

Article Info

Accepted:

15 January 2021

Available Online:

10 February 2021
Twelve botanicals were evaluated against Bipolaris setariae causing leaf blight on brown top millet under in vitro conditions at ICAR-AICRP on small millets. University of Agricultural Sciences, GKVK, Bangalore by poison food technique at 10, 20 and 30 per cent (w/v). Among the 12 botanicals Agave showed maximum inhibition of mean mycelial growth $(81.52 \%)$ and sporulation and also agave showed cent percent inhibition at 30 per cent concentration followed by datura and eucalyptus which accounted 40.62 and 34.32 per cent mean mycelial growth inhibition. Whereas, Calotropis was unableto inhibit the fungal growth and sporulation as evidenced by 0 per cent inhibition of mycelial growth. Similarly, Pongamia (1.48 \%), turmeric (1.77 $\%)$ and Gliricidia (9.46\%) extracts exhibited less inhibition of mycelial growth.

\section{Introduction}

Millets have been considering super grains since ages. With their nutritional value they became boon crops for human suffering with cardiac, diabetic and obese problems. They have recognized not only as smart crops for their capability of photo insensitivity, drought tolerance and climate resilience but also smart food because of their richness in vitamins, fibre and mineral content. Due to their importance FAO have approved and declared 2023 as International year of millets also India announced 2018 as national year of millets. Though the importance of millets is remarkable, the production accounts only 2 per cent of worlds cereal production where Asia accounts 40 per cent of millet production of the world.

As a cause of climate resilient and hardy nature and owing to their superior nutritional qualities, millets are gaining importance over cereals which were hitherto predominant (Anju and saritha, 2010). Browntop millet is native to India but was introduced to United States in 1915 for cultivation purpose (Oelke et al., 1990). It was recently included into millets system in India as one of the small millet for food and fodder purpose. Being 
different from other small millets by having characters like shortest growth period, shade tolerant, suppress root knot nematode and because of their sharp and stiff leaf structure it obstructs the entry of rats in to fields and also serves as cover crop and reduces soil erosion (Sujata et al., 2018).

As the millets are hindering from their potential yield production by the attack of several diseases like blast, blight or brown spot, downy mildews, smut, rust and other bacterial and viral diseases. Among them, blight or brown spot caused by Helminthosporia are most devastating next to blast. Browntop millet was first reported to be attacked by Bipolaris setariae causing leaf spot in Bihar (Misra and Prakash, 1972). In cropping system, sever incidence of leaf bight symptoms were noticed in the genotype evaluation trial (ICAR-AICRP on small millets) during Kharif 2018 and the disease was identified as Helminthosporium leaf blight (Anonymous, 2018-19).

Later, causal organism was identified as $B$. setariae using molecular markers. By considering the severity and prevalence of the disease in millet growing areas present study was undertaken as one of Integrated disease management (IDM) component to evaluate different botanicals against $B$. setariae under laboratory conditions.

\section{Materials and Methods}

In vitro evaluation of twelve plant extracts at three different concentrations viz., 10, 20 and 30 per cent were studied for their effect on growth and sporulation of $B$. setariae by using the poison food technique (Nene and Thapliyal, 1973; Sharvelle, 1961).

The different botanicals with plant parts used for extraction are listed in table 1. Extraction was done after washing the leaves of each plant thoroughly with running tap water and surface sterilized with 0.1 per cent sodium hypochlorite solution. The stock solutions of 100 per cent botanicals were made based on weight per volume (w/v) and stock solution of each plant extract were filtered through a muslin cloth.

An appropriate amount of botanical stock solution was added to the PDA medium, to obtain a required concentration of 10, 20 and 30 per cent and the conical flasks were gently shaken to completely disperse the botanical solution. About 15-20 ml of poisoned media was poured into $90 \mathrm{~mm}$ Petri dishes. $5 \mathrm{~mm}$ disc from 10 days old culture was taken by using an aseptic $9 \mathrm{~mm}$ cork borer and transferred to the centre of each Petri dish containing the poisoned medium.

A control was maintained in which the fungal pathogen was grown under similar conditions on agar medium without any plant extract. The inoculated plates were incubated at $27 \pm 1$ ${ }^{\circ} \mathrm{C}$ for 12 days and radial growth of the test pathogen was recorded in three directions and the average diameter was calculated. The percentage of inhibition of growth over control was calculated with the formula (Vincent, 1947).

$\mathbf{I}=\frac{(\mathbf{C}-\mathbf{T})}{\mathbf{C}} \times 100$

Where., I = Per cent inhibition. of mycelium

$\mathrm{C}=$ Growth of mycelium in control

$\mathrm{T}=$ Growth of mycelium in treatment

\section{Results and Discussion}

Twelve plant extracts were tested at three concentrations (10, 20 and $30 \%)$ using poisoned food technique to know the efficacy to inhibit the mycelial growth and sporulation of $B$. setariae (Table 2, Plate 1 and Fig. 1). Among the botanicals, highest significant 
mean per cent inhibition of mycelial growth was recorded in agave $(81.52 \%)$ whereas no inhibition was noticed in calotropis. In the other plant extarcts, the inhibition was moderate and variable. Amongst the concentrations, 30 per cent showed maximum (26.95\%) inhibition of mycelial growth with the least in 10 per cent $(10.08 \%)$.

With respect to interaction of botanicals and concentrations, complete mycelial growth inhibition was recorded in agave at 30 per cent. Agave was observed to be effective even at lower concentration than other botanicals at higher concentration.

Calotropis at all the concentrations, turmeric at 10 and 20 per cent and Aloe vera at 10 per cent showed no inhibition. Inhibition of mycelial growth was possibly due to inhibition of spore production, inhibition of spore germination and deformed conidia. Those botanicals that didn't affect the mycelial growth of $B$. setariae probably affected the conidia or sporulation.

Jatoi et al., (2015) recorded maximum inhibition of mycelial growth of $H$. oryzae in the ginger, garlic and datura extracts, but in our studies these extracts resulted only in moderate inhibition, with agave as the best. Subedi et al., (2019), Nayak and Hiremath (2019), Kumar et al., (2009), Sandeep (2015) and Gurjar et al., (2012) reported that neem (A. indica) and garlic were effective against Helminthosporium sp. in different crops.

These results were not in accordance present study where neem and garlic were found to be ineffective against $B$. setariae.

Table.1 List of Botanicals used for in vitro evaluation against $B$. setariae infecting browntop millet

\begin{tabular}{|c|l|l|l|l|}
\hline $\begin{array}{c}\text { SI. } \\
\text { No }\end{array}$ & \multicolumn{1}{|c|}{$\begin{array}{c}\text { Common } \\
\text { name }\end{array}$} & \multicolumn{1}{|c|}{ Scientific name } & \multicolumn{1}{|c|}{ Family } & Plant part used \\
\hline $\mathbf{1}$ & Turmeric & Curcuma longa L. & Zingiberaceae & Rhizome \\
\hline $\mathbf{2}$ & Garlic & Allium sativum L. & Amaryllidaceae & Bulb \\
\hline $\mathbf{3}$ & Ginger & Zingiber officinale Roscoe & Zingiberaceae & Rhizome \\
\hline $\mathbf{4}$ & Aloe vera & Aloe vera (L.) Burm. f. & $\begin{array}{l}\text { Asphodelaceae } \\
\text { (Liliaceae) }\end{array}$ & Succulent leaves \\
\hline $\mathbf{5}$ & Agave & Agave americana L. & Asparagaceae & Leaves \\
\hline $\mathbf{6}$ & Calotropis & Calotropis gigantea (L.) Dryand & Apocynaceae & Leaves \\
\hline $\mathbf{7}$ & Gliricidia & $\begin{array}{l}\text { Gliricidiasepium } \text { (Jacq.) Kunth } \\
\text { ex walp. }\end{array}$ & Fabaceae & Leaves \\
\hline $\mathbf{8}$ & Eucalyptus & Eucalyptus obliquaL'Her. & Myrtaceae & Leaves \\
\hline $\mathbf{9}$ & Datura & Datura metel L. & Solanaceae & Leaves \\
\hline $\mathbf{1 0}$ & Neem & Azadirachta indica A. Juss. & Meliaceae & Leaves \\
\hline $\mathbf{1 1}$ & Congress grass & Parthenium hysterophorus L. & Asteraceae & Leaves \\
\hline $\mathbf{1 2}$ & Karanj & Pongamia pinnata (L.) Pierre & Fabaceae & Leaves \\
\hline & & & & \\
\hline
\end{tabular}


Table.2 In vitro efficacy of botanicals against $B$. setariae infecting browntop millet

\begin{tabular}{|c|c|c|c|c|c|c|}
\hline \multirow[t]{2}{*}{ Sl. No. } & \multirow[t]{2}{*}{ Botanicals } & \multicolumn{3}{|c|}{ Per cent inhibition over control* } & \multirow[t]{2}{*}{ Mean } & \multirow[t]{2}{*}{ Microscopic observation } \\
\hline & & $10 \%(w / v)$ & $20 \%(w / v)$ & $30 \%(w / v)$ & & \\
\hline 1 & Turmeric & $0.00(0.29)$ & $0.00(0.29)$ & $5.31(13.21)$ & $1.77(4.60)$ & Sporulation (-) and deformed hyphae \\
\hline 2 & Garlic & $9.01(17.44)$ & $25.18(30.12)$ & $36.29(37.04)$ & $23.45(28.20)$ & Sporulation (-) \\
\hline 3 & Ginger & $3.94(11.44)$ & $7.40(15.71)$ & $20.98(27.25)$ & $10.77(18.13)$ & Sporulation (-) \\
\hline 4 & Aloe vera & $0.00 \quad(0.29)$ & $9.38(17.74)$ & $22.71(28.44)$ & $10.70(15.49)$ & Sporulation (-) \\
\hline 5 & Agave & $60.74(51.20)$ & $83.83(66.30)$ & $100.00(89.71)$ & $81.52(69.07)$ & Sporulation (-) \\
\hline 6 & Calotropis & $0.00(0.29)$ & $0.00 \quad(0.29)$ & $0.00(0.29)$ & $0.00(0.29)$ & Sporulation $(+++)$ but deformed shape \\
\hline 7 & Gliricidia & $0.49(2.52)$ & $10.86(19.21)$ & $17.03(24.35)$ & $9.46(15.36)$ & Sporulation $(+)$ but spore is $2-5$ celled \\
\hline 8 & Eucalyptus & $20.98(27.25)$ & $25.80(30.52)$ & $56.17(48.55)$ & $34.32(35.44)$ & Sporulation (-) \\
\hline 9 & Datura & $23.95(29.30)$ & $43.83(41.45)$ & $54.07(47.34)$ & $40.62(39.36)$ & Sporulation (-) \\
\hline 10 & Neem & $7.03(15.36)$ & $12.72(20.89)$ & $11.85(20.13)$ & $10.53(18.80)$ & Sporulation $(++++)$ \\
\hline 11 & $\begin{array}{l}\text { Congress } \\
\text { grass }\end{array}$ & $4.94(12.77)$ & $19.00(25.85)$ & $21.48(27.60)$ & $15.14(22.07)$ & Sporulation (-) \\
\hline \multirow[t]{5}{*}{12} & Karanj & $0.00(0.29)$ & $0.00 \quad(0.29)$ & $4.40(12.10)$ & $1.48(4.22)$ & Sporulation $(++)$ \\
\hline & Mean & $10.08(12.98)$ & $18.31(20.69)$ & 26.95 (28.95) & 19.98 & \\
\hline & & Botanicals (B) & Concentration (C) & $\mathrm{B} \times \mathrm{C}$ & & \\
\hline & S.Em \pm & 0.40 & 0.20 & 0.70 & & \\
\hline & $\mathrm{CD}(\mathrm{P} 0.01)$ & 1.14 & 0.55 & 1.98 & & \\
\hline
\end{tabular}

Note: * Mean of three replications; -: no sporulation; +: 1-15 conidia; ++: 16-45 conidia; +++: 46-70 conidia; ++++: >70 conidia per microscopic field. Figures in parenthesis are angular transformed values 
Fig.1 In vitro efficacy of plant extracts on mycelial growth inhibition of $B$. setariae

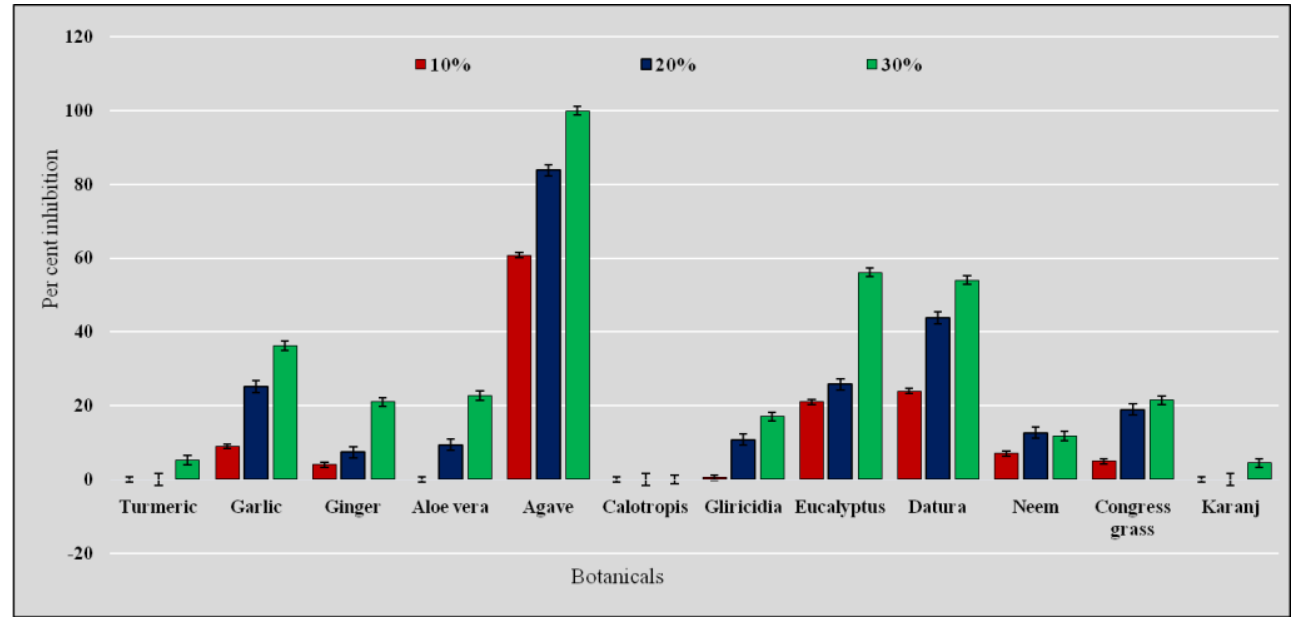

Plate.1 In vitro efficacy of different botanicals against B. setariae

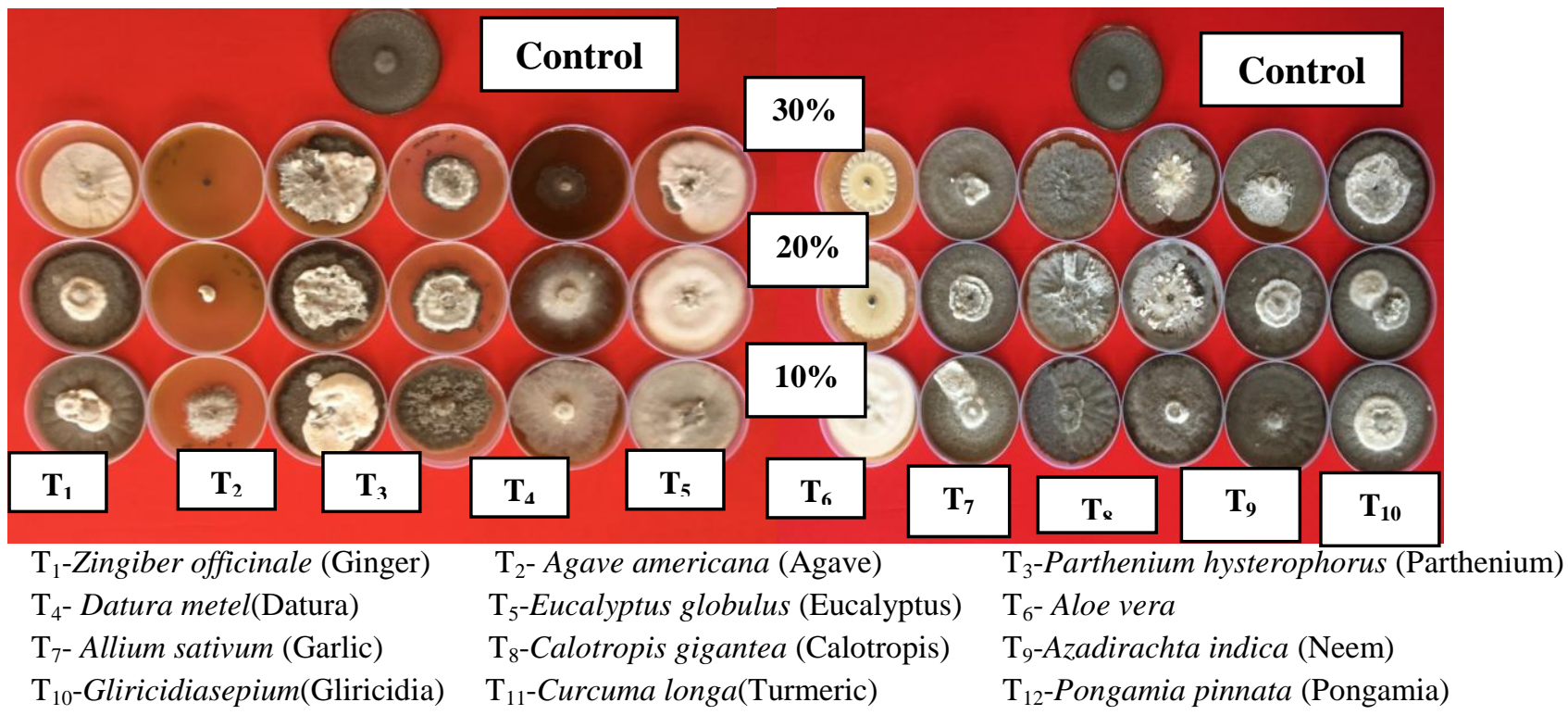

In conclusion among the 12 botanicals, significant mean highest percent inhibition of mycelial growth was noticed in agave $(81.52$ $\%)$ whereas no inhibition was observed in calotropis. Agave showed complete (100\%) inhibition at 30 per cent concentration. Sporulation was also not observed in Agave treatment where abundant sporulation in Calotropis treatment. The present study revealed that agave (Agave americana) as one of the promising botanicals against emerging leaf blight disease of browntop millet under in vitro conditions. However, efficacy of agave needs to be evaluated under field conditions in disease hot spot areas.

\section{Acknowledgment}

Authors thankful to Project Coordinating Unit, ICAR- AICRP on Small millets, Bengaluru for providing laboratory and other facilities. 


\section{References}

Anju, T. and Saritha, S.2010. Suitability of foxtail millet (Setaria italica) and barnyard millet (Echinochloa frumentacea) for development of low glycemic index biscuits. Mal. J. Nut. 16(3):361-368.

Oelke, E.A., Oplingerm E.S., Putnam, D.H., Durgan, B.R., Doll, and J.D. Millets. 1990. In: Alternative Field Crops Manual. Univ. of Wisc-Ext Serv. Univ. of Minn. Ext Serv and Univ. of Minn. CAPAP.

Sujata, B., Prabhu, C.G., Nandini, C., Prabhakar, and Thippeswamy, V. 2018. Browntop Millet- A Review. Agri. Res. \& Tech.: Open Access J. 14(5):555937.

Misra, A.P., and Prakash, O. 1972. Helminthosporium species occurring on graminaceous hosts in India. Indian J. Mycol. Pl. Pathol. 2:95-97.

Anonymous., 2018-19. Annual progress report of Indian Council of Agricultural research (ICAR)-All India CoOrdinated Research Project (AICRP) on small millets, Bengaluru.

Nene, Y.L., and Thapliyal, P.N. 1963. Fungicides in plant disease control. Oxford and IBH Publishing House, New Delhi, Pp. 163.

Sharvelle, E.G. 1961. The nature and use of modern fungicides. Burgess publishing Co., Minnesota, USA. Pp. 308.

Vincent, J.M. 1947. Distortion of fungal hyphae in the presence of certain inhibitors. Nature. 159: 850.

Jatoi, G.H., Abro, M.A., Memon, S., Hussain, S., Mangi, N., and Maari, S.A.2015.Efficacy of different Botanical extracts on the linear colony growth of the Helminthosporium oryzae. Eur. Acad. Res. 3(7):83838397.

Subedi, S., Neupane, S., Surendra, B.K., and Lokendra, O.L.I.2019.In vitro evaluation of botanicals, fungitoxic chemicals and bio-control agent for efficacy against turcicum leaf blight of maize. J. Nep. Agric. Res. Counc. 5:7380.

Nayak, M.S., and Hiremath, S.V.2019.In vitro Efficacy of Fungicides, Botanicals and Bioagents against Brown Leaf Spot of Rice Caused by Bipolaris oryzae. Int. J. Pure App. Biosci. 7(2): 375-381.

Kumar, S., Rani, A., and Jha, M.M. 2009. Evaluation of Plant Extracts for Management of Maydis Leaf Blight of Maize. Ann. Pl. Protec. Sci. 17(1):130132.

Sandeep, P. 2015. In vitro study of Fungicides in controlling Helminthosporium oryzae causal organism of Leaf brown spot of Rice. Int. Res. J. Biological Sci. 4(10):48-51.

Gurjar, M.S., Ali, S., Akhtar, N., and Singh, K.S. 2012. Efficacy of plant extracts in plant disease management. Agric. Sci. $3(3): 425-433$.

\section{How to cite this article:}

Gutha Venkata Ramesh, K. B. Palanna, Arunkumar, Boda Praveen and Nagaraja, A. 2021. In vitro Efficacy of Plant Extracts against Bipolaris setariae causing Brown Top Millet Leaf Blight. Int.J.Curr.Microbiol.App.Sci. 10(02): 1884-1889.

doi: https://doi.org/10.20546/ijcmas.2021.1002.223 